\title{
Design and syntheses of efficient and thermally stable diamino chromophores for NLO application
}

\author{
Wei Wu, Cheng Ye and Dong Wang* \\ Institute of chemistry, Chinese Academy of Sciences, Beijing 100080, China \\ E-mail: dwang210@yahoo.com
}

Dedicated to Professor Zhi-Tang Huang on his $75^{\text {th }}$ birthday

(received 25 Oct 02; accepted 20 Jan 03; published on the web 28 Jan 03)

\begin{abstract}
A novel series of diamino imidazole-type chromophores has been synthesized, which can be chemically incorporated into polymer matrices. Furthermore, their molecular optical nonlinearity, transparency and thermal stability were determined and studied comparatively. Theoretical calculation and experimental results indicate that good nonlinearity-transparencythermal stability is well balanced in chromophore 4 , which possesses a $\mu_{g} \beta_{0}$ of $554.8 \times 10^{-48}$ esu, a rather blue-shifted absorption peak at $384 \mathrm{~nm}$ in THF, and a high decomposition temperature $T_{\mathrm{d}}$ of $377^{\circ} \mathrm{C}$. It is strongly suggested from these results that multiple substitution strategy should be useful for designing novel NLO chromophores.
\end{abstract}

Keywords: Diamine-imidazole-type chromophore, NLO, thermal stability

\section{Introduction}

Organic molecules with large first hyperpolarizabilities $(\beta)$ have drawn considerable attention over the last 20 years for their potential applications in optical data storage, telecommunications and optical signal processing ${ }^{1,2}$. It is already well known that molecules that contain electrondonor and electron-acceptor groups separated by a large conjugated framework possess large values of $\beta .^{3}$ Many of these chromophores fall into the category of substituted benzenes, biphenyls, Schiff bases, stilbenes, azo stilbenes and tolans ${ }^{4,5}$. Molecular nonlinearities can be enhanced significantly by increasing the donor and acceptor strength or the length of the conjugation pathway. ${ }^{6}$

Although significant progress has accrued in the design and synthesis of such onedimensional dipole chromophores ${ }^{7,8}$, other properties, such as transparency, thermal stability and capability to be incorporated into bulk materials must also be optimized. Most NLO chromophores synthesized for electro-optic and frequency doubling application typically exhibit trade-off between nonlinearities and each of the other properties. ${ }^{9,10}$ For those traditional D- $\pi$-A chromophores, the increase in NLO response is usually accompanied by bathochromic shifts of the maximum absorption peak and decrease in thermal stability. 
In order for the nonlinear response to be stable during processing and operation, the chromophores need to be chemically stable at all temperatures that the system encounters. However, it is extremely difficult to achieve thermal stabilities of $300{ }^{\circ} \mathrm{C}$ or higher without concomitant compromise in the nonlinearity of the chromophore. Furthermore, in order to make a useful device, NLO chromophores must be incorporated into a fabric version, such as poled polymers, LB films, self-assembled or crystal environments, etc. Among these, chemical incorporation of chromophores into a polymer backbone is probably the most important and widely useful. For incorporation into polymers, the NLO chromophores must bear suitable reactive groups in the molecular structure. Up to now few such chromophores have been exploited, due to the difficulties in their synthesis. There exists a need to explore and develop such reactive chromophores with efficient nonlinearities, desired transparency and high thermal stabilities.

Herein we report initial studies on the synthesis and properties of a novel series of imidazolebased diamino chromophores, which can be used to form high $T_{\mathrm{g}}$ NLO poled polymers such as polyureas and polyimides for optimized thermal and physical properties.

\section{Results and Discussion}

Our approach to the design of superior nonlinear optical chromophores is based on the use of electron-rich five-membered heteroaromatics such as imidazole in the conjugation pathway. It is recognized that imidazole derivatives exhibit excellent thermal stability and solubility in conventional organic solvents. ${ }^{11}$ Meanwhile, it is possible to incorporate the chromophore into a polymer backbone, if two aminophenyl groups are introduced into the 4- and 5-positions of the imidazole ring.

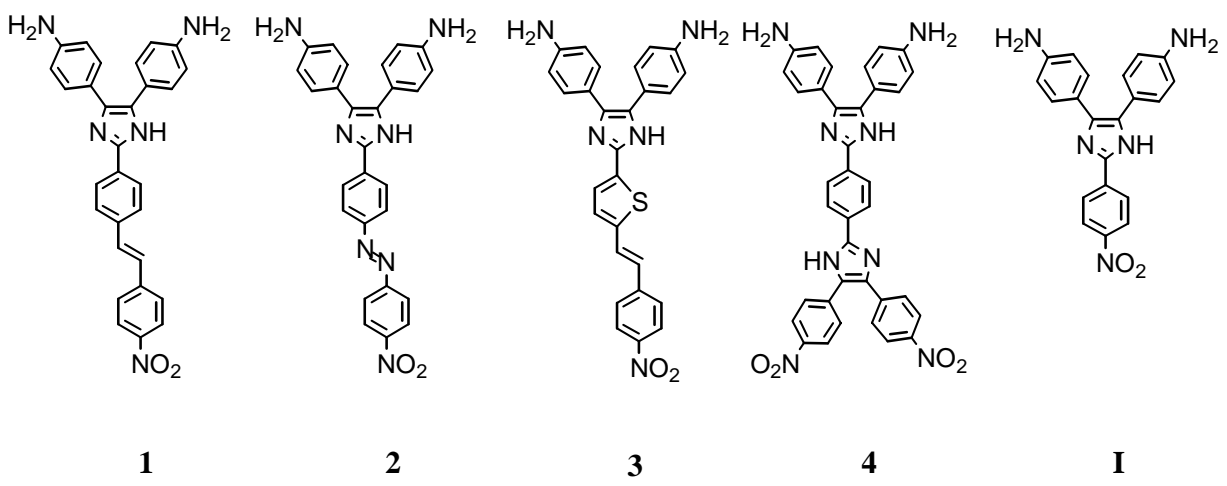

By connecting all four chromophores to an imidazole ring, we were able to produce extensively conjugated compounds that possess a stilbene moiety, an azo stilbene moiety, a thio stilbene moiety and another imidazole ring in the conjugation pathway. Amino groups were employed as the electron donor and nitro groups as the electron-acceptor. Chromophore 4, which bears two imidazole groups, is an X-type dual charge transfer (CT) system, which is favorable to obtain balanced nonlinearity-transparency-thermal stability properties.

To form the imidazole ring, condensation of benzil with aldehyde in the presence of 
ammonium acetate in glacial acetic acid solution is employed as a general method. The method to introduce amino groups into the structure becomes the key step for the syntheses. Marks and co-workers reported the use of 4,4-diphthalimidobenzil as a starting dicarbonyl compound. ${ }^{12}$ The condensation product bearing protected amino groups was deprotected by hydrazinolysis to afford the target chromophore. Since the use of bulky phthaloyl group for protecting amino group could result in poor solubility of the substrates and harsh reaction conditions for hydrazinolysis, the chromophores were produced in poor overall yield. The main modification is the use of the acetyl group, which can be removed under mild conditions, to protect amino functions. Compound $\mathbf{6}$ was prepared simply through $N$-acylation of $p$-aminobenzaldehyde 5 with acetic anhydride. Through benzoin condensation of $\mathbf{6}$ and subsequent oxidation of $\mathbf{7}$ with copper sulfate/pyridine, 4,4'-diacetamidobenzil $\mathbf{8}$ was prepared in good yield.

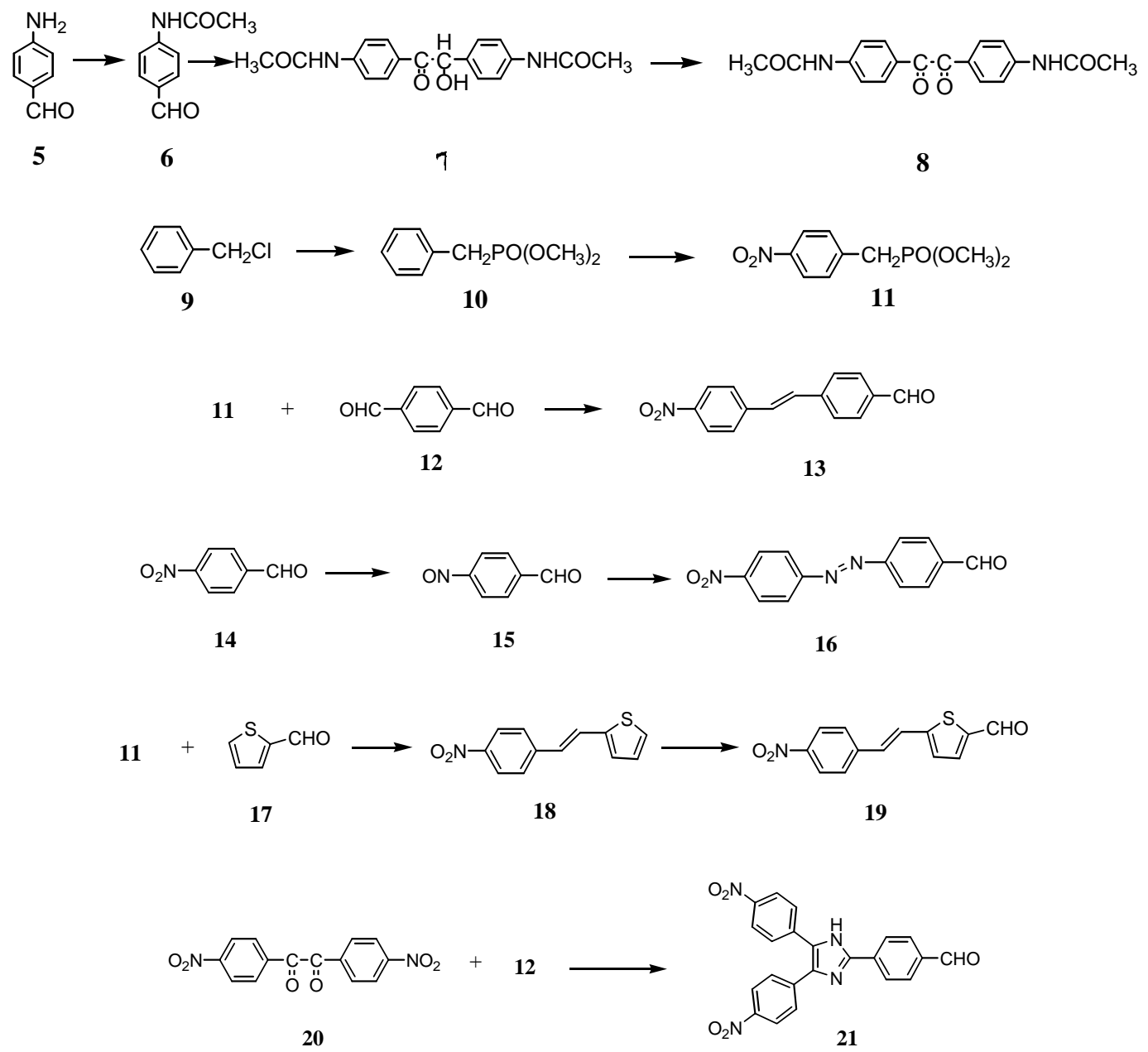




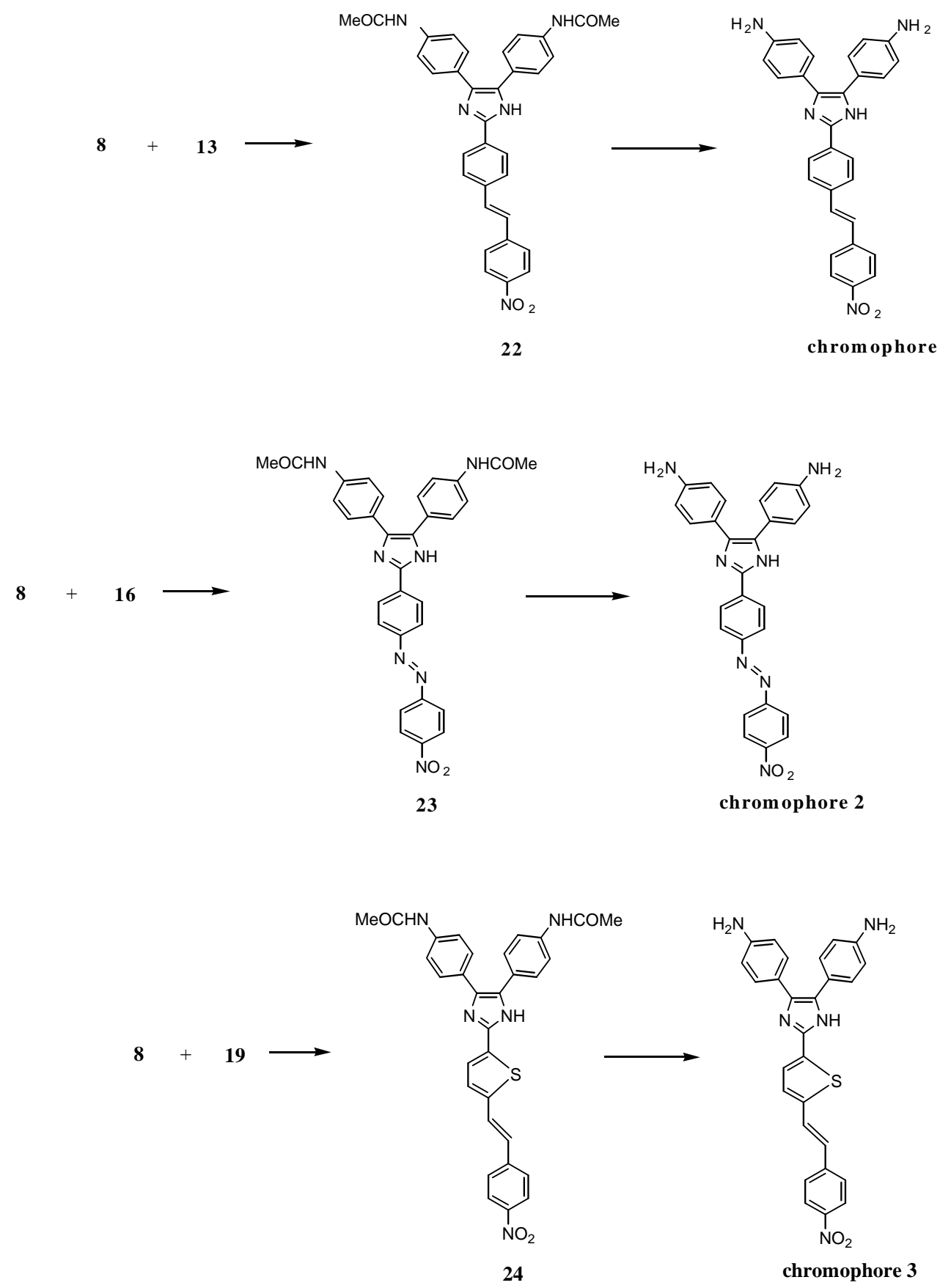




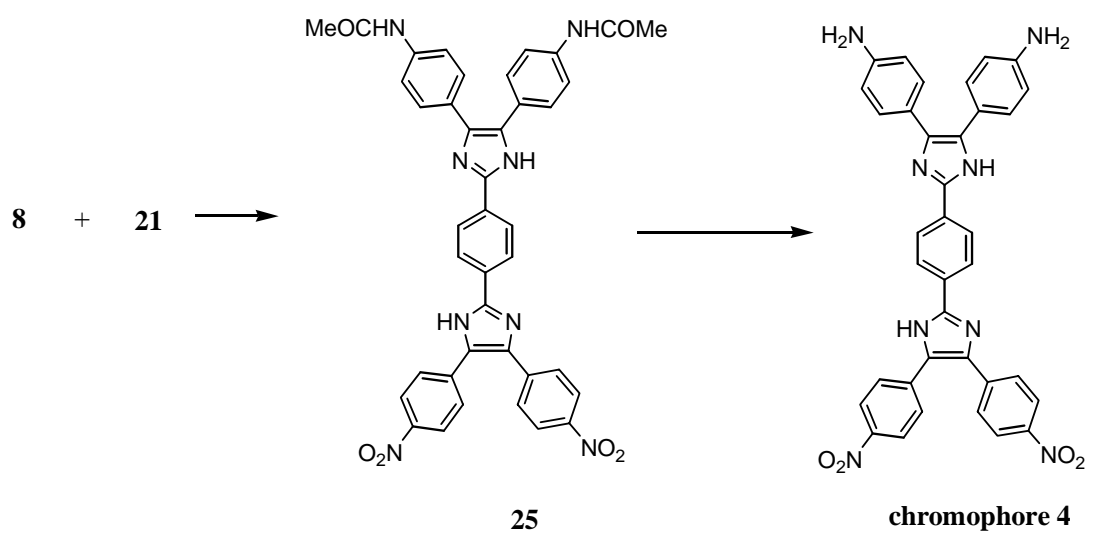

The syntheses of chromophores 1-4 are summarized in the above schemes. Phosphonate $\mathbf{1 0}$ was prepared by the Michaelis-Arbuzov reaction using benzyl chloride $\mathbf{9}$ and trimethyl phosphite. The nitro group in 4-position of the phenyl ring was introduced by nitration of $\mathbf{1 0}$ to afford 11. The Wadsworth-Emmons reaction of $p$-nitrophosphonate 11 with one equivalent of aldehyde 12 yielded aldehyde 13, which bears a trans-carbon-carbon double band and can be used to form an imidazole structure in the following step. Reduction of $p$-nitrobenzaldehyde $\mathbf{1 4}$ with zinc powder gave $p$-nitrosobenzaldehyde 15. Subsequently, Mills condensation of 15 with p-nitroaniline followed by treatment with acetic acid afforded aldehyde $\mathbf{1 6 .}$

Wadsworth-Emmons reaction of aldehyde $\mathbf{1 7 ^ { 1 3 }}$ with $p$-nitrophosphonate $\mathbf{1 1}$ gave product $\mathbf{1 8}$. Vilsmeier-Haack formylation reaction of $\mathbf{1 8}$ formed aldehyde $\mathbf{1 9}$ with a small amount of other isomer.

4,4'-Dinitrobenzil 20 was synthesized by Cremlyn's method ${ }^{14}$. Reaction of 20 with terephthaldicaboxaldehyde $\mathbf{1 2}$ in the presence of ammonium acetate in glacial acetic acid solution afforded aldehyde 21. This method is also employed to prepare chromophores 1-4. Reaction of dicarbonyl compound 8 with aldehydes 13, 16, 19, 21 yielded the corresponding diacetamido compounds 22, 23, 24, 25, which were further treated with $\mathrm{HCl} / \mathrm{MeOH}$ to give chromophores 1-4, respectively.

Theoretical investigation can play an important role in understanding structure-property relationship, which is able to assist in designing novel NLO chormophores. The electrostatic first hyperpolarizability $\beta$ and dipole moment $\mu$ of the four chromophores have been calculated by employing the semi-empirical AM1/FF (finite field) calculations. Characterization results for chromophores 1-4 are presented in Table 1. Characterization results for 2-(4-nitrophenyl)-4,5di(aminophenyl)imidazole (I) also are listed in Table 1 for comparison ${ }^{12}$.

Table 1. Characterization of Chromophores 1 4

\begin{tabular}{cccccc}
\hline chromophore & $\begin{array}{c}\lambda_{\max } \\
\mathrm{nm})\end{array}$ & $\begin{array}{c}\mu_{g} \\
(\mathrm{D})\end{array}$ & $\begin{array}{c}\beta_{0} / 10^{-30} \\
(\mathrm{esu})\end{array}$ & $\begin{array}{c}\mu_{g} \beta_{0} / 10^{-48} \\
(\mathrm{esu})\end{array}$ & $\begin{array}{c}T_{\mathrm{d}} \\
\left({ }^{\circ} \mathrm{C}\right)\end{array}$ \\
\hline 1 & 401 & 8.157 & 34.776 & 283.7 & 335 \\
2 & 461 & 8.182 & 41.816 & 342.1 & 344 \\
3 & 435 & 9.11 & 44.56 & 405.8 & 279 \\
4 & 384 & 10.90 & 50.912 & 554.8 & 377
\end{tabular}




\begin{tabular}{llllll}
$\mathbf{I}$ & 405 & 7.697 & 17.186 & 132.1 & 300 \\
\hline
\end{tabular}

It is found that all the four chromophores show larger $\mu_{g} \beta_{0}$ value than that of $\mathbf{I}$, which is attributed to the positive contribution of their elongated conjugation lengths. The azo chromophore 2 exhibits larger nonlinearity than the olefin chromophore 1, which indicates that the effect of $-\mathrm{N}=\mathrm{N}$ - moiety on the value of $\mu_{g} \beta_{0}$ is superior to that of $-\mathrm{CH}=\mathrm{CH}-$, but the $\lambda_{\max }$ of the former is red-shifted.

Comparison of chromophore 3 with chromophores 1 and 2 reveals that the replacement of the benzene ring by thiophene ring in conjugation pathway results in a greatly enhanced charge transfer properties and nonlinear responses. Chromophore 3 has the value of $\mu_{g} \beta_{0}: 405.8 \times 10^{-48}$ esu, which is larger than that of chromophore $1\left(342 \times 10^{-48} \mathrm{esu}\right)$ and $2\left(283.7 \times 10^{-48} \mathrm{esu}\right)$, but its $\lambda_{\max }$ is not the largest of the three. This can be explained as follow: since the delocalization energy of thiophene is lower than that of benzene ${ }^{15}$, the introduction of the thiophene ring as spacer between donor and acceptor would result in the loss of aromaticity in the ground state. However, this loss can be compensated by aromacity in the charge-separated form ${ }^{16}$. Most stilbene-type chromophores in which a benzene ring was replaced by a delocalized fivemembered heteroaromatic ring show significant increase in optical nonlinearities. These results clearly demonstrate the importance of thiophene-like rings in the design of push-pull chromophores. For one-dimensional push-pull chromophores, either increasing the conjugation length or changing the $\pi$-conjugation system inevitably results in enhancement of their chargetransfer properties.

For the two-level model of chromophore, it is clear that the hyperpolarizability is a strong function of the absorption maximum. Since even a small absorption at the operating wavelength of electron-optic devices can be detrimental, it is important to make NLO chromophores as transparent as possible without compromising the molecule's nonlinearity. From the results listed in Table 1, it can be seen that chromophore 4 performs rather well in the nonlinearitytransparency trade-off. Its $\mu_{g} \beta$ value is $c a$. twice that of chromophore $\mathbf{1}$, but its $\lambda_{\max }$ value is blueshifted by ca. $17 \mathrm{~nm}$ due to the presence of two charge-transfer states in similar energy levels, each of which can contribute to the hyperpolarizability. The results indicate that $\beta$ of chromophore $\mathbf{4}$ arises from multiple excited configurations as reported by Ye and co-workers ${ }^{17}$. Obviously, due to its poor co-planarity and the multiple substitution strategy, chromophore 4 does not have a strengthened CT structure. Thermal stability of the four chromophores was estimated by thermogravimetric analysis (TGA). All samples show very high decomposition temperature $\left(T_{\mathrm{d}}\right)$ above $250{ }^{\circ} \mathrm{C}$ measured at a heating rate of $20^{\circ} \mathrm{C} / \mathrm{min}$, which makes them ideal candidates for incorporation into high temperature polymers for device application. For chromophore 3, the lowest $T_{\mathrm{d}}\left(279{ }^{\circ} \mathrm{C}\right)$ may be due to the introduction of thiophene ring. Comparison of $T_{\mathrm{d}}$ of chromophore 1 with that of chromophore 2 reveals that azo moiety is thermally more stable than the olefin moiety in this type of compounds. Among the four chromophores, chromophore 4 in particular possesses very high $T_{\mathrm{d}}\left(377^{\circ} \mathrm{C}\right)$, which is attributed to the absence of azo, olefin, thiophene groups in its structure.

In summary, a novel series of diamino imidazole-type chromophores has been synthesized. The molecular optical nonlinearity, transparency and thermal stability were determined and 
studied comparatively. The theoretical calculation and experimental results indicate that nonlinearity-transparency-thermal stability of chromophore $\mathbf{4}$ is well balanced, which possesses a $\mu \beta_{0}$ of $555 \times 10^{-48}$ esu, rather blue-shifted absorption peak at $384 \mathrm{~nm}$ in THF and high decomposition temperature $T_{\mathrm{d}}$ of $377^{\circ} \mathrm{C}$. All the four novel chromophores can be used to form high $\mathrm{Tg}$ polymers for nonlinear optical applications.

\section{Experimental Section}

General Procedures. All new compounds were fully characterized with standard spectroscopic techniques. ${ }^{1} \mathrm{H}$ NMR and ${ }^{13} \mathrm{C}$ NMR spectra were recorded on a Varian XL-200 NMR Spectrometer. Infrared spectra were recorded using a Perkin-Elmer system 1760 FTIR spectrometer. Microanalysis was performed on a Calro 1102 element analysis instrument. Electronic absorption (Uv-vis) spectra were recorded using a Shanghai $756 \mathrm{MC}$ Uv-vis spectrometer. The inherent thermal stability was determined by thermogravimetric analysis (TGA) by using PE-7 series under the heating rate of $20^{\circ} \mathrm{C} / \mathrm{min}$.. The onset of the decomposition was obtained by the intercept of the leading edge of the weight loss curves.

Synthesis of 6. To $12.5 \mathrm{~mL}$ acetic anhydride in a round-bottomed flask was added fresh $p$ aminobenzaldehyde $5(10 \mathrm{~g})$ at once. After the exothermic reaction was set in, the mixture was poured into cold water. The precipitate was collected by filtration and recrystallized from $50 \%$ ethanol. The product 6 (12 g) was obtained as a colorless crystal. yield $89.1 \% . \mathrm{mp} 157 \sim 159^{\circ} \mathrm{C} .{ }^{1} \mathrm{H}$ $\operatorname{NMR}\left(\mathrm{CDCl}_{3}\right) \delta(\mathrm{ppm}) 9.92(\mathrm{~s}, 1 \mathrm{H}), 7.93(\mathrm{~s}, \mathrm{br}, 1 \mathrm{H}), 7.85(\mathrm{~d}, 2 \mathrm{H}, J=6.8 \mathrm{~Hz}), 7.72(\mathrm{~d}, 2 \mathrm{H}, J=$ $6.8 \mathrm{~Hz}) ; 2.24(\mathrm{~s}, 3 \mathrm{H})$.

Synthesis of 7. To a solution of $6(10 \mathrm{~g}, 61 \mathrm{mmol})$ in $95 \%$ alcohol $(50 \mathrm{~mL})$ was added $\mathrm{NaCN}$ $(0.8 \mathrm{~g})$ and one drop of aqueous $10 \% \mathrm{NaOH}$. The mixture was refluxed for $2 \mathrm{~h}$. After cooling, the mixture was poured in water $(100 \mathrm{~mL})$. The resultant precipitate was collected by filtration and purified by recrystallization from 50\% aqueous acetic acid, to afford compound 7 (2.85 g, 28.5\%) mp184 185 ${ }^{\circ} \mathrm{C} .{ }^{1} \mathrm{H}$ NMR $\left(\mathrm{CDCl}_{3}+\mathrm{DMSO}_{\mathrm{d}}\right) \delta(\mathrm{ppm}) 9.96(\mathrm{~s}, 1 \mathrm{H}), 9.60(\mathrm{~s}, 1 \mathrm{H}), 7.85$ (d, $2 \mathrm{H}, J=8.0 \mathrm{~Hz}), 7.64(\mathrm{~d}, 2 \mathrm{H}, J=8.0 \mathrm{~Hz}), 7.56(\mathrm{~d}, 2 \mathrm{H}, J=8.0 \mathrm{~Hz}), 7.28(\mathrm{~d}, 2 \mathrm{H}, J=8.0 \mathrm{~Hz}), 5.90$ $(\mathrm{d}, 1 \mathrm{H}, J=6.0 \mathrm{~Hz}), 5.22(\mathrm{~d}, 1 \mathrm{H}, J=6.0 \mathrm{~Hz}), 2.11(\mathrm{~s}, 1 \mathrm{H}), 2.09(\mathrm{~s}, 1 \mathrm{H})$.

Synthesis of 8. Copper sulfate pentahydrate $(5 \mathrm{~g})$ was added to a mixture of fresh pyridine (10 $\mathrm{mL})$ and water $(3 \mathrm{~mL})$. The reaction mixture was heated for $30 \mathrm{~min}$ till a homogenous bright blue solution was obtained. Then to this solution was added compound 7 ( $2 \mathrm{~g}, 6.13 \mathrm{mmol})$. The mixture was stirred at $100{ }^{\circ} \mathrm{C}$ for $3 \mathrm{~h}$. The resulting dark green solution was poured into water $(250 \mathrm{~mL})$. Crude product was filtered and purified by recrystallization from $50 \%$ aqueous acetic acid to yield compound $8(1.85 \mathrm{~g}, 93.6 \%) \mathrm{mp} 248^{\circ} \mathrm{C} .{ }^{1} \mathrm{H}$ NMR (DMSO-d $\left.{ }_{6}\right) \delta(\mathrm{ppm}) 10.30(\mathrm{~s}$, 2H), $7.80(\mathrm{~s}, 8 \mathrm{H}), 2.14(\mathrm{~s}, 6 \mathrm{H})$.

Synthesis of 10. To neat benzyl bromide $(25 \mathrm{~mL}, 0.2 \mathrm{~mol})$ was added trimethyl phosphite (40 $\mathrm{mL}, 0.375 \mathrm{~mol})$. the mixture was refluxed at $110-120{ }^{\circ} \mathrm{C}$ for $18 \mathrm{~h}$. The lower boiling point substances were removed by distillation. Then the crude product was distilled under reduced 
pressure, giving compound 10 as a colorless liquid $(33.4 \mathrm{~g})$. yield $83.5 \%$. bp $130^{\circ} \mathrm{C} / 1 \mathrm{mmHg}$. ${ }^{1} \mathrm{H} \mathrm{NMR}\left(\mathrm{CDCl}_{3}\right) \delta(\mathrm{ppm}) 7.3(\mathrm{~s}, 5 \mathrm{H}), 3.65(\mathrm{~d}, 2 \mathrm{H}, J=11.0 \mathrm{~Hz}) ; 3.16(\mathrm{~d}, 3 \mathrm{H}, J=11.0 \mathrm{~Hz})$.

Synthesis of 11. To the cold mixed acid $\left(20 \mathrm{~mL} \mathrm{H}_{2} \mathrm{SO}_{4}\right.$ and $\left.20 \mathrm{~mL} \mathrm{HNO}_{3}\right)$ was added compound 10 (20 g, $0.1 \mathrm{~mol})$ dropwise at $0-2{ }^{\circ} \mathrm{C}$ over a period of $30 \mathrm{~min}$. The cold bath was removed and the mixture was stirred at ambient temperature for another $30 \mathrm{~min}$. The resultant mixture was poured in $1000 \mathrm{~mL}$ of ice water and then separated between benzene and water. The organic layer was washed and dried over magnesium sulfate. After the removal of benzene, compound $\mathbf{1 1}$ (22.6 g) was obtained as a viscous liquid with high purity. Yield 92.6, $\mathrm{mp} 37^{\circ} \mathrm{C},{ }^{1} \mathrm{H}$ NMR $\left(\mathrm{CDCl}_{3}\right) \delta(\mathrm{ppm}) 8.21(\mathrm{~d}, 2 \mathrm{H}, J=9.2 \mathrm{~Hz}), 7.48(\mathrm{~d}, 2 \mathrm{H}, J=9.2 \mathrm{~Hz}), 3.76(\mathrm{~d}$, $2 \mathrm{H}, J=11.0 \mathrm{~Hz}), 3.22(\mathrm{~d}, 3 \mathrm{H}, J=22.4 \mathrm{~Hz})$.

Synthesis of 15. To a solution of p-nitrobezaldehyde $14(24 \mathrm{~g}, 0.159 \mathrm{~mol})$ in alcohol $(200 \mathrm{~mL})$ was added acetic acid $(36 \mathrm{~mL})$. At vigorous stirring, zinc powder (100 mesh, $24 \mathrm{~g}$ ) was then added separately. The reaction mixture was stirred at room temperature for $30 \mathrm{~min}$ and then filtered. To the filtrate was added $10 \%$ aqueous ferric chloride $(240 \mathrm{~mL})$ and stirred overnight. The resultant yellow solid was collected by filtration, followed by fast steam distillation, $2.4 \mathrm{~g}$ compound 15 was obtained as a yellow solid. Yield $11 \%$ m.p. $128-130{ }^{\circ} \mathrm{C}$. The product was carried over to the next step without further characterization.

Synthesis of 16. To a solution of p-nitroaniline $(2.0 \mathrm{~g}, 14.5 \mathrm{mmol})$ in acetic acid $(40 \mathrm{~mL})$ was added compound $15(0.6 \mathrm{~g}, 4.8 \mathrm{mmol})$. The reaction mixture was heated to reflux for $5 \mathrm{~min}$, then cooled to room temperature. The resultant red precipitate was filtered and added to $1 \mathrm{M}$ aqueous $\mathrm{HCl}(60 \mathrm{~mL})$. The mixture was stirred at $80^{\circ} \mathrm{C}$ for $1 \mathrm{~h}$, followed by refluxing for $3 \mathrm{~h}$. The thus formed precipitate in hot solution was collected by filtration, washed with water and recrystallized from acetic acid to give compound $16(0.5 \mathrm{~g}$, yield $44 \%) . \mathrm{mp} 221-222{ }^{\circ} \mathrm{C} .{ }^{1} \mathrm{H}$ NMR (DMSO-d 6 ) $\delta(\mathrm{ppm}) 8.17$ (m, 6H), $8.42(\mathrm{~d}, 2 \mathrm{H}), 10.18(\mathrm{~s}, 1 \mathrm{H})$.

\section{General procedure for the Wadsworth -Emmons reaction of the aldehydes12, 17 with} phosphonate 11

To a 1:1 mixture of the aldehyde and the p-nitrophosphonate $\mathbf{1 1}$ in THF solution was added equivalent potassium $t$-butoxide. The resultant mixture was stirred at room temperature for $3 \mathrm{~h}$. After filtration, and removal of the solvent, the crude product was purified by recrystallization from ethyl acetate.

Compound 13. Characterizing data. A yellow solid. m.p. 138-140 ${ }^{\circ} \mathrm{C} .{ }^{1} \mathrm{H}$ NMR $\left(\mathrm{CDCl}_{3}\right) \delta$ (ppm) $9.97(\mathrm{~s}, 1 \mathrm{H}), 8.00(\mathrm{~d}, 2 \mathrm{H}, J=8.5 \mathrm{~Hz}), 7.62(\mathrm{~d}, 2 \mathrm{H}, J=8.5 \mathrm{~Hz}), 7.22(\mathrm{~s}, 2 \mathrm{H})$.

Compound 18. Characterizing data. A bright yellow crystal. mp. $168-170{ }^{\circ} \mathrm{C} .{ }^{1} \mathrm{H}$ NMR (DMSO$\left.\mathrm{d}_{6}\right) \delta(\mathrm{ppm}) 8.22(\mathrm{~d}, 2 \mathrm{H}, J=9.5 \mathrm{~Hz}), 7.58(\mathrm{~d}, 2 \mathrm{H}), 7.18(\mathrm{~d}, 4 \mathrm{H}, J=9.5 \mathrm{~Hz}), 7.42(\mathrm{~d}, 1 \mathrm{H}, J=16.4$ $\mathrm{Hz}), 7.32 \sim 7.20(\mathrm{~m}, 3 \mathrm{H}), 6.95(\mathrm{~d}, 1 \mathrm{H}, J=16.4 \mathrm{~Hz}) .{ }^{13} \mathrm{C}$ NMR $\left(\mathrm{DMSO}_{6}\right) \delta(\mathrm{ppm}) 146.7,143.5$, 141.7, 128.0, 127.9, 126.5, 126.2, 126.1, 125.7, 124.1. $\mathrm{m} / \mathrm{z}(\mathrm{EI}): 231\left(\mathrm{M}^{+}\right)$. Anal. Calcd. for $\mathrm{C}_{12} \mathrm{H}_{9} \mathrm{NO}_{2} \mathrm{~S}: \mathrm{C}, 62.34 \mathrm{H}, 3.91 ; \mathrm{N}, 6.06 \%$. Found: $\mathrm{C}, 62.23 ; \mathrm{H}, 3.91 ; \mathrm{N}, 5.94 \%$.

Synthesis of 19. Phosphorus oxychloride $(0.768 \mathrm{~g}, 5 \mathrm{mmol})$ was added dropwise at $0{ }^{\circ} \mathrm{C}$ to DMF $(2 \mathrm{~mL})$. The mixture was stirred at $0{ }^{\circ} \mathrm{C}$ for $1 \mathrm{~h}$ and room temperature for $30 \mathrm{~min}$. To the resulting solution was then added compound $18(1.155 \mathrm{~g}, 5 \mathrm{mmol})$ at once. This reaction mixture was heated to $80 \sim 90{ }^{\circ} \mathrm{C}$ and maintained at this temperature for $6 \mathrm{~h}$. After cooling, the mixture was poured into water $(50 \mathrm{~mL})$. The yellow solid was collected by filtration, washed 
with water and recrystallized from ethyl acetate to give 19 (1.15 g, yield $54.2 \%)$, mp. $133{ }^{\circ} \mathrm{C}$. IR (KBr) cm ${ }^{-1}: 3042,2900,1645,1534,1503,1438,1330,1218,942,652 .{ }^{1} \mathrm{H}$ NMR (DMSO$\left.\mathrm{d}_{6}\right) \delta(\mathrm{ppm}) 9.90(\mathrm{~s}, 1 \mathrm{H}), 8.25(\mathrm{~d}, 2 \mathrm{H}, J=8.5 \mathrm{~Hz}), 8.01(\mathrm{~d}, 1 \mathrm{H}, J=3.8 \mathrm{~Hz}), 7.86(\mathrm{~d}, 2 \mathrm{H}, J=8.5$ $\mathrm{Hz}), 7.79(\mathrm{~d}, 1 \mathrm{H}, J=16.0 \mathrm{~Hz}), 7.52(\mathrm{~d}, 1 \mathrm{H}, J=3.8 \mathrm{~Hz}), 7.42(\mathrm{~d}, 1 \mathrm{H}, J=16.0 \mathrm{~Hz}) .{ }^{13} \mathrm{C} \mathrm{NMR}$ $\left(\mathrm{DMSO}_{\mathrm{d}}\right), \delta$ (ppm) 182.7, 136.9, 133.6, 133.3, 129.1, 128.9, 128.2, 127.6, 127.5, 125.5, 125.0. $\mathrm{m} / \mathrm{z}(\mathrm{EI}): 259\left(\mathrm{M}^{+}\right)$. Anal. Calcd. for $\mathrm{C}_{13} \mathrm{H}_{9} \mathrm{NO}_{3} \mathrm{~S} \cdot \mathrm{C}, 60.21 ; \mathrm{H}, 3.51 ; \mathrm{N}, 5.40 \%$. Found: C, 60.48; H, 3.97; N, 5.39\%.

\section{General Procedure of the syntheses of imidazole derivatives 21-25 from aldehyde 12, 13,} 16, 19, 21

A mixture of benzil compound and aldehyde (1:1), ammonium acetate (10 eq.) in glacial acetic acid was stirred at $110^{\circ} \mathrm{C}$ for $2 \mathrm{~h}$ under nitrogen. After cooling, the resulting homogeneous solution was poured over crushed ice. The precipitate was collected by filtration and washed with cold water, then dried under vacuum. The crude product was recrystallized from ethyl acetate to afford the imidazole derivatives.

Compound 21. Characterization data. mp. $>300{ }^{\circ} \mathrm{C}$ IR $(\mathrm{KBr}) \mathrm{cm}^{-1}: 3400,1686,1592,1500$, 1435, 1334, 1200, 1100, 841, 685. ${ }^{1} \mathrm{H}$ NMR (DMSO-d 6$) \delta(\mathrm{ppm}) 10.00(\mathrm{~s}, 1 \mathrm{H}) ; 8.80 \sim 8.30(\mathrm{~m}$, $8 \mathrm{H}) ; 7.78(\mathrm{~s}, 4 \mathrm{H}) .{ }^{13} \mathrm{C}$ NMR $\left(\mathrm{DMSO}_{-} \mathrm{d}_{6}\right) \delta(\mathrm{ppm})$ 172.8, 148.2, 146.4, 142.2, 139.6, 138.2, 135.0, 130.4, 129.8, 128.4, 126.2, 124.4, 124.2. m/z (EI): 414 Anal. Calcd for $\mathrm{C}_{22} \mathrm{H}_{14} \mathrm{~N}_{4} \mathrm{O}_{5}: \mathrm{C}, 63.71 \%$; H, 3.41\%; N, 13.51\%. Found: C, 63.36\%; H, 3.79\%; N, 13.15\%.

Compound 22. Characterization data. mp: $>300{ }^{\circ} \mathrm{C}$, IR $(\mathrm{KBr}) \mathrm{cm}^{-1} 3450,2920,1650,1598$, 1510, 1340, 1160,1010,470. ${ }^{1} \mathrm{H}$ NMR $\left(\mathrm{DMSO}_{-} \mathrm{d}_{6}\right) \delta(\mathrm{ppm}): 10.00(\mathrm{~s}, 1 \mathrm{H}), 8.26(\mathrm{~d}, 2 \mathrm{H}, J=8.6$ $\mathrm{Hz}), 8.14(\mathrm{~d}, 2 \mathrm{H}, J=8.6 \mathrm{~Hz}) ; 7.90(\mathrm{~d}, 2 \mathrm{H}, J=8.6 \mathrm{~Hz}) ; 7.79(\mathrm{~d}, 2 \mathrm{H}, J=8.6 \mathrm{~Hz}) ; 7.7 \sim 7.4(\mathrm{~m}$, $12 \mathrm{H}), 2.08(\mathrm{~s}, 6 \mathrm{H}) .{ }^{13} \mathrm{C}$ NMR (DMSO-d $) \delta(\mathrm{ppm}) 166.4,155.4,151.2,148.5,143.8,134.1$, 128.3, 126.1, 126.0, 125.2, 123.9, 129.5, 118.9, 24.1. $\mathrm{m} / \mathrm{z}$ (FAB) 557. Anal. Calcd for $\mathrm{C}_{33} \mathrm{H}_{27} \mathrm{~N}_{5} \mathrm{O}_{4}$ : C, 71.08\%; H, 4.88\%; N, 12.56\%. Found: C, 71.00\%; H, 5.19\%; N, 12.88\%.

Compound 23. Characterization data. $\mathrm{mp}:>300^{\circ} \mathrm{C}$, IR $(\mathrm{KBr}) \mathrm{cm}^{-1} 3350,1640,1600,1520$, 1490, 1400, 1350, 850. ${ }^{1} \mathrm{H}$ NMR (DMSO-d 6$) \delta(\mathrm{ppm}) 10.00(\mathrm{~s}, 1 \mathrm{H}) ; 8.44(\mathrm{~d}, 2 \mathrm{H}, J=9.0 \mathrm{~Hz})$, $8.38(\mathrm{~d}, 2 \mathrm{H}, J=9.0 \mathrm{~Hz}), 8.17(\mathrm{~d}, 2 \mathrm{H}, J=9.0 \mathrm{~Hz}), 8.15(\mathrm{~d}, 2 \mathrm{H}, J=9.0 \mathrm{~Hz}), 7.8 \sim 7.4(\mathrm{~m}, 8 \mathrm{H})$, $2.04(\mathrm{~s}, 6 \mathrm{H}) .{ }^{13} \mathrm{C}$ NMR $\left(\mathrm{DMSO}_{6}\right) \delta(\mathrm{ppm}) 166.3,155.4,151.2,148.5,143.9,136.8,134.0$, 126.2, 126.0, 125.2, 123.9, 123.5, 118.8, 24.1. $\mathrm{m} / \mathrm{z}$ (FAB), 559. Anal. Calcd for $\mathrm{C}_{33} \mathrm{H}_{27} \mathrm{~N}_{5} \mathrm{O}_{4} 2 \mathrm{H}_{2} \mathrm{O}: \mathrm{C}, 62.52 \%$; H, 4.91\%; N, 16.46\%. Found: C, 62.76\%; H, 5.10\%; N, $16.15 \%$.

Compound 24. Characterization data. mp. $>300{ }^{\circ} \mathrm{C}$. IR $(\mathrm{KBr}) \mathrm{cm}^{-1}: 3400,1657,1580,1515$, 1435, 1400, 1327, 1100, 830. ${ }^{1} \mathrm{H}$ NMR (DMSO-d 6 ) $\delta(\mathrm{ppm}) 12.81(\mathrm{~s}, 1 \mathrm{H}), 10.08(\mathrm{~s}, 1 \mathrm{H}), 9.94$ $(\mathrm{s}, 1 \mathrm{H}) ; 8.22(\mathrm{~d}, 2 \mathrm{H}, J=8.6 \mathrm{~Hz}), 7.83(\mathrm{~d}, 2 \mathrm{H}, J=8.6 \mathrm{~Hz}), 7.62(\mathrm{~d}, 1 \mathrm{H}, J=3.4 \mathrm{~Hz}), 7.30(\mathrm{~d}$, $1 \mathrm{H}, J=16.0 \mathrm{~Hz}), 7.32(\mathrm{~d}, 1 \mathrm{H}, J=3.4 \mathrm{~Hz}), 7.5 \sim 7.38(\mathrm{~m}, 8 \mathrm{H}), 7.13(\mathrm{~d}, 1 \mathrm{H}, J=16.0 \mathrm{~Hz}) .{ }^{13} \mathrm{C}$ NMR $(\text { DMSO-d })_{6} \delta(\mathrm{ppm}) 168.8,145.7,143.4,141.0,140.4,138.3,138.2,133.8,130.6,129.4$, 127.7, 126.7, 126.2, 125.4, 118.6. $\mathrm{m} / \mathrm{z}(\mathrm{FAB}): 564\left(\mathrm{M}^{+}\right)$. Anal. Calcd. for $\mathrm{C}_{13} \mathrm{H}_{9} \mathrm{NO}_{3} \mathrm{~S} \cdot \mathrm{C}$, 64.02; H, 4.68; N, 12.04\% Found:.C, 63.85, H, 4.92; N, 12.46\%.

Compound 25. Characterization data. mp. $>300{ }^{\circ} \mathrm{C}$, IR $(\mathrm{KBr}) \mathrm{cm}^{-1} 3400,2910,1660,1510$, 1330, 1100, 1010, 850, 460. ${ }^{1} \mathrm{H}$ NMR (DMSO-d 6 ) $\delta(p p m) 13.22$ (s, 1H), 12.66 (s, 1H), 10.71 
$(\mathrm{s}, 1 \mathrm{H}), 9.50(\mathrm{~s}, 1 \mathrm{H}), 8.4 \sim 8.2(\mathrm{~m}, 8 \mathrm{H}) ; 7.84(\mathrm{~d}, 2 \mathrm{H}), 7.80(\mathrm{~d}, 2 \mathrm{H}), 7.7 \sim 7.4(\mathrm{~m}, 8 \mathrm{H}), 2.54(\mathrm{~s}$, $6 \mathrm{H}) .{ }^{13} \mathrm{C}$ NMR (DMSO-d $\left.{ }_{6}\right) \delta(\mathrm{ppm}) 168.4,147.5,146.7,146.1,144.7,141.4,139.0,137.5$, $136.8,131.2,129.4,128.9,128.3,128.0,126.1,125.8,124.2,124.0,118.9,24.2 . \mathrm{m} / \mathrm{z}$ (FAB), 719. Anal. Calcd for $\mathrm{C}_{40} \mathrm{H}_{30} \mathrm{~N}_{8} \mathrm{O}_{6}$ : C, 66.84\%; H, 4.21\%; N, 15.59\%. Found: C, 66.27\%; H, $4.57 \%$; N, 15.21\%.

\section{General procedure for the syntheses of chromophores 1 4 from 22 25}

A solution of 22 25 in methanol with concentrated hydrochloric acid was refluxed for $30 \mathrm{~min}$. After cooling to room temperature, the resulting yellow solution was poured over crushed ice. The precipitate was filtered and dissolved in water. To this aqueous solution was added ammonia liquor dropwise to the $\mathrm{pH} 10 \sim 11$. Thus formed precipitate was collected by filtration and washed with cold water, and then dried under vacuum. Flash column chromatography was performed to afford the pure chromophores $\mathbf{1} \sim \mathbf{4}$ correspondingly.

Chromophore 1. Characterization data. m.p. $>300{ }^{\circ} \mathrm{C}$. IR $(\mathrm{KBr}) \mathrm{cm}^{-1}: 3365,3214,3031,1622$, 1590, 1504, 1340, 1288, 1182, 1110, 967, 843, 750. ${ }^{1} \mathrm{H}$ NMR (DMSO-d $) \delta(\mathrm{ppm}) 12.30(\mathrm{~s}$, $1 \mathrm{H}), 8.28(\mathrm{~d}, 2 \mathrm{H}, J=9 \mathrm{~Hz}), 8.07(\mathrm{~d}, 2 \mathrm{H}, J=9 \mathrm{~Hz}), 7.90(\mathrm{~d}, 2 \mathrm{H}, J=9.0 \mathrm{~Hz}), 7.75(\mathrm{~d}, 2 \mathrm{H}, J=9.0$ $\mathrm{Hz}$ ), 7.53 (d, 2H, olefin), 7.23 (brs, 4H), 6.55 (brs, 4H), 5.21 (brs, 2H), 5.02 (brs, $2 \mathrm{H}) .{ }^{13} \mathrm{C}$ NMR (DMSO-d $\left.)_{6}\right), \delta(\mathrm{ppm}) 146.3,144.6,144.2,138.5,136.0,132.6,130.5,128.2,127.6$, 127.4, 126.6, 125.5, 124.2, 119.0. m/z(EI): $473\left(\mathrm{M}^{+}\right)$. Anal. Calcd. for $\mathrm{C}_{29} \mathrm{H}_{23} \mathrm{~N}_{5} \mathrm{O}_{2}$ : C, 73.56; H, 4.90; N, 14.78\%. Found: C, 73.80; H, 5.11; N, 14.59\%.

Chromophore 2. Characterization data. m.p. $>300^{\circ} \mathrm{C}$. IR $(\mathrm{KBr}) \mathrm{cm}^{-1}: 3374,3214,3029,1604$, 1522, 1497, 1344, 1289, 1141, 967, 858, 697. ${ }^{1} \mathrm{H}$ NMR (DMSO-d $) \delta(p p m) 12.50(\mathrm{~s}, 1 \mathrm{H}), 8.42$ $(\mathrm{d}, 2 \mathrm{H}, J=9.0 \mathrm{~Hz}), 8.27(\mathrm{~d}, 2 \mathrm{H}, J=9.0 \mathrm{~Hz}), 8.09(\mathrm{~d}, 2 \mathrm{H}, J=9.5 \mathrm{~Hz}), 8.02(\mathrm{~d}, 2 \mathrm{H}, J=9.5 \mathrm{~Hz})$, $7.20(\mathrm{~d}, 4 \mathrm{H}, J=9.5 \mathrm{~Hz}), 6.52(\mathrm{~d}, 4 \mathrm{H}, J=9.5 \mathrm{~Hz}), 5.30$ (brs, $2 \mathrm{H}), 5.20$ (brs, $2 \mathrm{H}) .{ }^{13} \mathrm{C}$ NMR $\left(\right.$ DMSO-d $\left._{6}\right) \delta(\mathrm{ppm}) 165.6,151.0,150.2,146.4,148.0,142.7,134.4,128.7,125.7,125.3$, 124.1, 123.6, 113.6. m/z (EI): 473( $\left.\mathrm{M}^{+}\right)$. Anal. Calcd. for $\mathrm{C}_{27} \mathrm{H}_{21} \mathrm{~N}_{7} \mathrm{O}_{2}: \mathrm{C}, 68.20 ; \mathrm{H}, 4.45 ; \mathrm{N}$, 20.62\%. Found: C, 67.84; H, 4.74; N, 20.28\%.

Chromophore 3. Characterization data. m.p. $>300^{\circ} \mathrm{C}$. IR $(\mathrm{KBr}) \mathrm{cm}^{-1}: 3400,1608,1576,1500$, 1435, 1325, 1172, 1100, 825. ${ }^{1} \mathrm{H}$ NMR (DMSO-d 6 ) $\delta(\mathrm{ppm}) 12.25$ (s, 1H), 8.21 (d, 2H, J=8.6 $\mathrm{Hz}), 7.82(\mathrm{~d}, 2 \mathrm{H}, J=8.6 \mathrm{~Hz}) 7.66(\mathrm{~d}, 1 \mathrm{H}, J=16.4 \mathrm{~Hz}), 7.60(\mathrm{~d}, 1 \mathrm{H}, J=3.8 \mathrm{~Hz}), 7.30(\mathrm{~d} 1 \mathrm{H}, J=$ $3.8 \mathrm{~Hz}), 7.20(\mathrm{~d} 4 \mathrm{H}, J=8.5 \mathrm{~Hz}) .7 .14(\mathrm{~d} 1 \mathrm{H}, J=16.4 \mathrm{~Hz}) 6.58(\mathrm{~d}, 4 \mathrm{H}, J=8.5 \mathrm{~Hz}) .{ }^{13} \mathrm{C}$ NMR $\left(\right.$ DMSO-d $\left._{6}\right) \delta$ (ppm) 146.0, 143.7, 142.9, 141.3, 140.7, 133.4, 130.1, 128.6, 128.4, 128.1, 127.7, 127.1, 126.6, 125.6, 124.6, 124.0, 118.9. HR-MS $\left(\mathrm{M}^{+}\right)$. Anal. Calcd. for $\mathrm{C}_{27} \mathrm{H}_{21} \mathrm{~N}_{5} \mathrm{O}_{2} \mathrm{~S} \cdot$ : 479.1417, Found: 479.1410

Chromophore 4. Characterization data. m.p. $>300{ }^{\circ} \mathrm{C}$. IR $(\mathrm{KBr}) \mathrm{cm}^{-1}: 3384,3214,2913,1613$, 1599, 1515, 1342, 1289, 1181, 1110, 969, 855, 702. ${ }^{1} \mathrm{H}$ NMR (DMSO-d 6 ) $\delta$ 9ppm) $13.09(\mathrm{~s}$, $1 \mathrm{H}), 12.50(\mathrm{~s}, 1 \mathrm{H}), 8.34(\mathrm{~d}, 2 \mathrm{H}, J=9.0 \mathrm{~Hz}), 8.23(\mathrm{~d}, 2 \mathrm{H}, J=9.0 \mathrm{~Hz}), 8.23(\mathrm{~d}, 2 \mathrm{H}, J=9.0 \mathrm{~Hz})$, $8.18(\mathrm{~d}, 4 \mathrm{H}), 7.85(\mathrm{~d}, 2 \mathrm{H}, J=9.0 \mathrm{~Hz}), 7.23(\mathrm{~d}, 4 \mathrm{H}, J=9.5 \mathrm{~Hz}), 6.55(\mathrm{~d}, 4 \mathrm{H}, J=9.5 \mathrm{~Hz}), 5.10$ (brs, 4H). ${ }^{13} \mathrm{C}$ NMR (DMSO-d 6 ) $\delta$ (ppm) 147.5, 146.7, 146.1, 141.3, 137.5, 136.8, 130.8, 129.4, 128.8, 128.3, 128.0, 126.1, 125.7, 124.2, 124.0, 118.9. m/z(FAB): $635\left(\mathrm{M}^{+}\right)$. Anal. Calcd. for $\mathrm{C}_{36} \mathrm{H}_{26} \mathrm{~N}_{8} \mathrm{O}_{4} \cdot 2 \mathrm{H}_{2} \mathrm{O}$ : C, 64.47; H, 4.51; N, 16.70\%. Found: C, 64.20; H, 4.42; N, 16.27\%. 


\section{Acknowledgements}

This project is financially supported by The National Natural Science Foundation of China.

\section{References}

1. Prasad, P. N.; Williams; D. J. Introduction to Nonlinear Optical Effects in Organic Materials and Polymers Wiley, New York, 1991.

2. Chemla, D.S.; Zyss, J. Nonlinear Optical Properties of Organic Molecules and Crystals, Academic Press, New York, 1987.

3. Williams, D.J. Angew. Chem., Int. Ed. Engl. 1984, 23, 690.

4. Cheng,L.-T.; Tam,W.; Stevenson,S.H.; Meredith,G.R.; Rikken, G.; Marder, S.R. J. Phys. Chem. 1991, 95, 10631.

5. Cheng,L.-T.; Tam,W.; Marder, S.R.; Stiegman, A.E.; Rikken, G.; Spangler, C.W. J. Phys. Chem. 1991, 95, 10643.

6. Barzoukas, M.; Blanchard-Desce, M.; Josse, D.; Lehn, J-M.; Zyss, J. J. Chem. Phys. 1989, 133, 323.

7. Jen, A.K.-Y.; Cai, Y.; Bedworth, P.V. Adv. Mater. 1997, 9, 132.

8. Doltan, L.R. Chem. Ind. (London) 1997, 7, 510.

9. Moylan, C.R.; Miller, R.D.; Twieg, R.J.; Lee, V.Y.; McComb, L.H.; Ermer, S.; Lovejoy, S.M.; Leung, D.S. Proc. SPIE-int. Soc. Opt. Eng. 1995, 2527, 150

10. Burland, D.S.; Miller, R.D.; Reiser, O.; Twieg, R.J.; Walsh, C.A. J. Appl .Phys. 1992, 71, 420

11. Li, H.;Bu, R.; Ahemed, M.; Mintz, E.A. Polym. Prepr. 1996, 37, 599.

12. Wand, J.; Marks, T.J.; Lin, W. Polym. Prepr. 1995, 36, 308.

13. Gever, G. J. Am. Chem. Soc. 1953, 75, 4585.

14. Cremlyn, R.J.; Swinbourne, F.J. J. Heterocycl. Chem. 1987, 117.

15. Wheland, F. Resonance in Organic Chemistry, Wiley, New York, 1955, 99.

16. Marder, S.R.; Beratan, D.N.; Cheng, L.-T. Science 1991, 252, 103

17. Wang, P.; Zhu, P.;.Wu, W.; Kang, H.; Ye, C. Phys. Chem. Chem. Phys. 1999, 1, 3519. 